\title{
Afweging van kosten en nut bij steekproeven in de accountantscontrole
}

\author{
Prof. J.H. Blokdijk
}

\section{Inleiding}

De accountantscontrole wordt sinds het midden der jaren tachtig beheerst door de risico-analyse. De mate van zekerheid die aan de accountantscontrole kan worden ontleend wordt gebaseerd op een gewenst uiteindelijk accountantscontrolerisico; hoewel Statement on Auditing Standards 39 (SAS 39) van het Amerikaanse Instituut (AICPA, 1981) hier slechts sprak van 'audit risk', duidden Arens en Loebbecke dit in 1988 aan met 'Desired Audit Risk'.

Dit laatste pleegt dan door accountants in een samenwerkingsverband (maatschap, accountantsdienst) bij wijze van beleidsuitspraak voor hun gehele controlepraktijk te worden vastgesteld. In navolging van het voorbeeld dat het American Institute of Certified Public Accountants in de Appendix bij SAS 39 (AICPA, 1981) geeft, is het Desired Audit Risk door menig samenwerkingsverband van accountants op 5\% gesteld. De vraag is: is dit gewenste accountantscontrolerisico ook aanvaardbaar, met name voor de gebruikers van accountantsverklaringen? In dit verband is het tekenend, dat Arens en Loebbecke in een latere druk van hun boek (1991) de eerdergenoemde term wijzigen in 'Acceptable Audit Risk'.

De kwantificering van dit accountantscontrolerisico speelt in de techniek van de accountantscontrole alleen een rol bij de bepaling of al dan niet, en zo ja, in welke omvang, deelwaarnemingen zullen worden toegepast. Indien de deelwaarnemingen worden uitgevoerd in de vorm van statistische steekproeven, is de kwantificering van risico's onvermijdelijk; de kwantitatieve vorm van risicoanalyse speelt dan ook vooral een rol bij de toepassing van statistische steekproeven.

$\mathrm{Nu}$ is de enige theoretische rechtvaardiging voor de aanvaarding van risico in de accountantscontrole gelegen in een afweging van nut en kosten (NIvRA 1982, p. 35). Onder het nut wordt met name verstaan: het nut voor de gebruikers van de accountantsverklaring, waaronder met name de al dan niet anonieme belanghebbenden buiten de organisatie van de gecontroleerde van betekenis zijn. Het nut van accountantscontrole is gelegen in de mate van zekerheid omtrent de getrouwheid van het door de jaarrekening gegeven beeld; het risico van een niet getrouw beeld, het accountantscontrolerisico, is het complement van deze zekerheid.

De vaststelling van het accountantscontrolerisico zal bij vele samenwerkingsverbanden van accountants onder eenzijdige druk hebben gestaan, namelijk van de zijde van de verantwoordingsplichtigen die in eerste instantie ook de kosten van de accountantscontrole dragen; de stem van de gebruikers van de accountantsverklaringen kan nu eenmaal veel minder worden gehoord. De vaststelling van een percentage voor het samenwerkingsverband als geheel duidt daar ook op: een echte afweging van nut en kosten zal zeker niet in alle gevallen tot hetzelfde aanvaardbare risico leiden.

Prof. J.H. Blokdijk, registeraccountant, is directeur van J.H. Blokdijk Advies B.V. en adviseur van ondernemingen en accountants. Hoogleraar toegepaste Accountantscontrole aan de Vrije Universiteit Amsterdam. Heeft vele vaktechnische functies bij het NIvRA vervuld. Lid van het bestuur van de Stichting Toezicht Effectenverkeer. 


\section{MAB}

Dit geldt in beginsel voor alle vormen van deelwaarneming die in de accountantscontrole worden toegepast, niet alleen bij statistische steekproeven. Een onderzoek naar andere mogelijkheden is echter bij de statistische steekproef het eenvoudigst, omdat deze procedure is gebaseerd op kwantitatieve gegevens: de tolerantie en het risico van ten onrechte aanvaarding. Bij de tolerantie, als uitdrukking van de materialiteit, wordt in beginsel reeds algemeen uitgegaan van de behoeften van gebruikers van verantwoordingen en accountantsverklaringen, doch dit geldt, zoals geschetst, niet - of hooguit globaal en indirect voor het risico. Daarom verdient dit laatste thans de aandacht.

In dit artikel wordt onderzocht of het nut voor de gebruikers van accountantsverklaringen een groter gewicht kan worden gegeven door de afweging van nut en kosten bij de bepaling van het aanvaardbare risico bij statistische steekproeven in de accountantscontrole.

\section{Eerdere pogingen tot afweging van nut en kosten}

De eerste poging tot een kwantitatieve afweging van nut en kosten ter vaststelling van de omvang van statistische steekproeven is reeds in 1961 gepubliceerd door A. van Heerden, in het artikel waarin hij de Guldenrang nummermethode introduceerde (Van Heerden, 1961).

Ten aanzien van het nut hanteerde hij twee premissen:

1 het 'nut' van het vinden van een fout bij de accountantscontrole is (maximaal) gelijk aan het bedrag van die fout;

2 het risico van niet-ontdekking mag worden ingecalculeerd door vermenigvuldiging van dat risico met het bedrag waarover het risico wordt gelopen.

Van Heerden kwam vervolgens tot een maximale economisch verantwoorde steekproefomvang door een klassieke marginale afweging van het aldus gekwantificeerde nut en de kosten: hij berekende de steekproefomvang waarbij de door toevoeging van één trekking aan de steekproef veroorzaakte afneming van het produkt van steekproefrisico en het bedrag waarover het risico wordt gelopen, gelijk is aan de kosten van die éne trekking. Hij kwam daarmee tot een uiterst simpele en elegante formule, uitgaande van de 'klassieke' steekproeftheorie.

De formule van Van Heerden leidt naar de huidige gevoelens tot steekproeven van grote omvang, ook al zijn de kosten van accountantscontrole sinds 1961 aanmerkelijk gestegen. Ook toen al zag Van Heerden mogelijkheden voor een geringere steekproefomvang dan waartoe zijn eerderbedoelde formule leidde. Daarom heeft hij in hetzelfde artikel nog een poging gedaan de invloed van de toepassing van andere controlemaatregelen op de steekproefsgewijs te controleren populatie in de steekproefomvang te verwerken, waarmee hij in feite vooruitliep op de risico-analyse. $\mathrm{Hij}$ introduceerde daarbij een reductiefactor, die hij rechtstreeks toepaste op de steekproefomvang en niet, zoals de risico-analyse sedertdien met meer recht heeft gedaan, op het steekproefrisico.

Naar mijn mening is zijn als eerste gepresenteerde methode, zonder reductiefactor, eveneens voor verbetering vatbaar; ik kom hier in de volgende paragraaf van dit artikel op terug. Toch heeft Van Heerden een formidabele prestatie geleverd; het heeft dan ook bijna dertig jaar geduurd voordat het thema: afweging van nut en kosten, opnieuw in de literatuur aan de orde is gesteld.

Dit geschiedde door R. Metzer, die zich daarbij niet baseerde op de 'klassieke' steekproeftheorie, maar een meer 'Bayesiaanse' methode koos (Metzer, 1989).

De keuze tussen deze twee scholen in de steekproeftheorie is thans een strijdpunt tussen die accountants die zich met de steekproeftheorie bezig houden (zie bijvoorbeeld Riegman, 1991). Een praktisch verschil is, dat de berekeningen volgens de Bayesiaanse methode veel ingewikkelder zijn dan die volgens de klassieke methode; een theoretisch verschil is dat de klassieke methode (te) voorzichtig is.

Metzer geeft dan ook aan dat voor zijn methode computerprogrammatuur onontbeerlijk is; moeilijk 
valt echter uit zijn artikel na te gaan hoe die programmatuur opgezet zou moeten worden. Als principieel bezwaar tegen zijn artikel kan worden aangevoerd dat het niet duidelijk aangeeft hoe het 'geldelijk belang', dat evenals bij Van Heerden een wezenlijk element is bij de berekening van het nut van de steekproef, wordt bepaald.

\section{Een nieuwe poging: de gedachtengang}

In het navolgende waag ik een nieuwe poging tot de bepaling van de omvang van statistische steekproeven door afweging van nut en kosten. Ik zal mij daarbij baseren op de 'klassieke' steekproeftheorie, zonder daarmee partij te willen kiezen in de huidige, in de voorgaande paragraaf genoemde strijd. In de 'klassieke' steekproeftheorie zijn de formules en berekeningen nu eenmaal aanmerkelijk eenvoudiger dan in de 'Bayesiaanse', hetgeen het de lezer gemakkelijker maakt mijn gedachten te doorgronden. Of deze ook van toepassing kunnen zijn in de 'Bayesiaanse' steekproeftheorie ware vervolgens door anderen te onderzoeken, omdat dit de wiskundige vaardigheden van schrijver dezes vermoedelijk ver te boven zou gaan. Het is evenwel denkbaar dat de eerdergenoemde strijd tussen de 'klassieke' en de 'Bayesiaanse' benadering aan betekenis inboet (zie paragraaf 5 hierna).

Mijn eerderbedoelde kritiek op Van Heerden is, dat deze geen rekening heeft gehouden met de materialiteit. in wezen weegt elk foutje, hoe klein ook, bij Van Heerden mee. Zelf wil ik mij baseren op dezelfde gedachtengang als Van Heerden: een marginale afweging tussen de toename van het nut en de toename van de kosten. Als 'nut' zie ik echter de vermindering van het risico van niet-ontdekking van een totale fout ter grootte van de bij de controle toepasselijke tolerantie, als uitdrukking van de materialiteit. Deze benadering leidt tot steekproeven van aanmerkelijk geringere omvang dan bij Van Heerden.

Alvorens de uitkomsten van deze benadering te beschrijven schenk ik eerst aandacht aan enkele aspecten van het nut en van de kosten.

\section{De kwantificering van het nut}

Van Heerden stelt het nut van het vinden van een fout (maximaal) gelijk aan het bedrag van die fout. Metzer nuanceert dit: hij voert naast het 'geldelijk-belangbedrag' ook een 'geldelijk-belangfactor' in, maar op dit laatste punt is hij niet duidelijk. Bij het nut van de steekproef is de volgende kanttekening te maken.

De bepaling van de steekproefomvang vindt uiteraard plaats bij de 'planning' van de controle. Daarbij moet rekening gehouden worden met de meest ongunstige redelijkerwijs te verwachten foutenmogelijkheid. In het algemeen is dat: een fout in het (netto)resultaat. Immers, een belegger/aandeelhouder pleegt de waarde van zijn bezit te toetsen aan de koers/winstverhouding; dat is het belangrijkste kengetal dat bemiddelaars bij belegging (banken, commissionairs) plegen op te nemen in hun publikaties ten behoeve van beleggers. Dit betekent dat een fout in het nettoresultaat voor deze gebruikers van de jaarrekening en de accountantsverklaring een geldelijk belang kan hebben ter grootte van de fout vermenigvuldigd met de koers/winstverhouding! Dit zou betekenen dat bij de afweging van kosten en nut het bedrag van de tolerantie zou moeten worden vermenigvuldigd met de koers/winst-verhouding.

Het vorenstaande illustreert dat er een rechtstreeks verband kan bestaan tussen het nut van de steekproef voor de gebruikers van de jaarrekening en de omvang van fouten, indien deze althans in totaal boven de tolerantie uitgaan. Deze gedachte wordt naar mijn mening ondersteund door de bevindingen van Huijgen en Plantinga die zijn weergegeven in een recent artikel in dit blad (Huijgen en Plantinga, 1993). Zij concluderen dat verschillen in koers/winstverhoudingen voor een groot deel worden verklaard door verschillen in groeiverwachtingen. Dan worden fouten in winstcijfers nog gevoeliger: een ten onrechte te hoog gepresenteerde winstgroei leidt dan tot een ten onrechte te hoge koers/winstverhouding, dus in wezen tot een (later optredende) dubbele schade! Uiteraard kan het omgekeerde zich ook voordoen; daarom wordt voorshands geen rekening gehouden met deze mogelijke dubbele schade. 
De introductie van de koers/winstverhouding in de beschouwing doet echter de vraag rijzen of Van Heerden dus toch gelijk had toen hij - naar mijn mening onbewust - elke fout in de afweging betrok; immers, elke fout in het nettoresultaat beïnvloedt de uitkomst van de vermenigvuldiging van dat resultaat met de koers/winstverhouding. Het komt mij voor dat dit te ver zou voeren: de koers/winstverhouding pleegt te fluctueren zonder dat het laatst bekende resultaat verandert. Deze fluctuaties lijken mij de grondslag te vormen voor de tolerantie in het nettoresultaat.

Wel dient nog een technisch aspect in de beschouwing te worden betrokken. De bij de accountantscontrole gehanteerde tolerantie heeft in het algemeen betrekking op jaarrekeningposten die zijn begrepen in het belastbaar bedrag voor de winstbelasting, zodat correctie van fouten in het resultaat in het algemeen tot correctie in het belastbaar bedrag voor de winstbelasting leidt. De koers/winstverhouding heeft echter betrekking op het resultaat na winstbelasting, zodat bij de beoogde afweging van nut en kosten de tolerantie gecorrigeerd moet worden voor het belastingeffect.

Tenslotte: de kwantificering van het nut van de controle. Van Heerden deed dit door, zoals gezegd, het risico van niet-ontdekking te vermenigvuldigen met het bedrag waarover het risico wordt gelopen. Een dergelijke benadering wordt ook in andere takken van wetenschap wel gevolgd, zoals ter de bepaling van de waarde van informatie (zie bijvoorbeeld Bromwich, 1987, p. 48). Ook lijkt mij deze premisse maatschappelijk geaccepteerd: het is bijvoorbeeld de basis voor de berekening van verzekeringspremies. Daarom sluit ik mij op dit punt bij Van Heerden aan.

\section{De kwantificering van de kosten}

Aan de (controle)kosten heb ik reeds eerder nadere invulling gegeven (Blokdijk, 1969). Deze kosten worden uiteindelijk gedragen door de eigenaren, die stellig - naast de gecontroleerde zelf - belangrijke belanghebbenden zijn bij de met de controle te scheppen zekerheid. Daarom dienen de kosten te worden gecalculeerd zoals zij aan de gecontroleerde in rekening worden gebracht, dus tegen de door de accountant gehanteerde tarieven. Wel moet het tarief bij de afweging van nut en kosten worden gebaseerd op de minst gekwalificeerde medewerker die de desbetreffende controle deugdelijk kan uitvoeren. De kosten van de controle komen ten laste van de winst van de gecontroleerde, en zijn in de afweging ten behoeve van eerdergenoemde gebruikers dus onderworpen aan dezelfde koers/winstverhouding. Voorts plegen de accountantskosten aftrekbaar te zijn voor de winstbelasting, zodat bij de afweging van nut en kosten ook hier een reductie van bruto naar netto zou moeten plaatsvinden.

\section{Een nieuwe poging: de uitkomst}

De afweging van nut en kosten kan nu naar mijn mening als volgt geschieden. De kans op nietontdekking van een totale fout ter grootte van de tolerantie kan bij elke steekproefomvang uitgerekend worden, dus ook de vermindering van die kans als de steekproefomvang één trekking groter zou zijn. Die vermindering van de kans op nietontdekking is bij kleine steekproefomvangen groter dan bij grote steekproefomvangen; bij elke vergroting van de steekproef wordt die vermindering kleiner. Als de vermindering van die kans vermenigvuldigd met het bedrag van de tolerantie gelijk wordt aan de (variabele) kosten verbonden aan de controle van één trekking, dan is de optimale steekproefomvang gevonden. Een grotere steekproefomvang betekent verspilling, een kleinere dat belanghebbenden bij de jaarrekening in hun zekerheid te kort gedaan worden.

Deze procedure is dezelfde die Van Heerden heeft gepropageerd: een afweging van het marginale nut met de marginale kosten. Daarom worden slechts de met de omvang variërende kosten van de steekproefprocedure in aanmerking genomen.

De uitkomst van vorenstaande gedachtengang is voor steekproeven waarbij men de populatie uitsluitend bij het aantreffen van 0 fouten goedkeurt, neergelegd in een formule, die - samen met de 


\section{MAB}

bewijsvoering - is opgenomen in paragraaf 3 van de Appendix bij dit artikel. Daaruit blijkt, dat de koers/winst-verhouding en de belastingreductie van bruto naar netto in de vergelijking tegen elkaar wegvallen, zodat zij verder buiten de hierna volgende beschrijving van de procedure blijven.

Voor de bepaling van de optimale steekproefomvang moet de volgende procedure worden uitgevoerd. Men vermenigvuldige de variabele controlekosten per eenheid met het totaalbedrag van de te onderzoeken populatie, en dele dit produkt door het kwadraat van het bedrag van de tolerantie. De aldus gevonden uitkomst is de noodzakelijke betrouwbaarheid van de steekproef. Deze uitkomst zoeke men op in een tabel van de enkelvoudige Poisson-verdeling, bijvoorbeeld zoals opgenomen in NIvRA-geschrift 25 (NIvRA 1982, p. 168), in de kolom $k=0$. Vervolgens neme men het bedrag in de voorkolom, vermenigvuldige dat met het totaalbedrag van de te controleren populatie en dele dit produkt door het bedrag van de tolerantie; de uitkomst is de gezochte steekproefomvang.

Dit lijkt ingewikkelder dan het is; bij de thans gebruikelijke bepaling van de steekproefomvang doet men al grotendeels hetzelfde, maar die handelingen zijn veelal reeds geautomatiseerd. De nieuw toegevoegde handelingen zijn eveneens gemakkelijk te automatiseren. Wil men deze berekeningen handmatig uitvoeren, dan zal men waarschijnlijk moeten beschikken over een langere en meer verfijnde tabel van de enkelvoudige Poissonverdeling dan die welke is opgenomen in NIvRA-geschrift 25.

De procedure is dezelfde indien men een steekproef wenst toe te passen waarbij men ook bij het aantreffen van 1 , of 2 , of méér fouten wenst goed te keuren. Dan zoeke men in de kolom $k=1$ respectievelijk $k=2$ respectievelijk $k=$ het hoogste aantal fouten waarbij men nog wenst goed te keuren. De bewijsvoering is weergegeven in paragraaf 4 van de Appendix. Zoals bekend, worden de steekproeven groter naarmate men daarin méér fouten wenst te aanvaarden, maar dergelijke steekproeven kunnen nuttig zijn om een verwacht groot risico van ten onrechte afkeuren te verminderen.
Een cijfervoorbeeld kan verhelderend werken.

Stel:

- het totaalbedrag van de te controleren populatie

- het bedrag van de tolerantie $f$ 100.000,-

- het uurtarief van de laagst gekwalificeerde assistent die de controle deugdelijk kan verrichten $f \quad 60$,-

- het aantal posten dat deze, inclusief opzoeken en dergelijke, in een uur kan controleren

- het aantal fouten waarbij de populatie goedgekeurd wordt

Dan is het steekproefrisico als volgt te bepalen:

$$
\begin{array}{r}
60 / 6 * 2.000 .000 \\
100.000 * 100.000
\end{array}=0,002
$$

De daarbij behorende waarde in de voorkolom van de tabel van de enkelvoudige Poissonverdeling is: 6,0 .

De steekproefomvang wordt dan:

$$
\begin{gathered}
6,0 * 2.000 .000 \\
100.000
\end{gathered}=120 \text { stuks. }
$$

Volgens de formule van Van Heerden, zonder reductiefactor, zou de steekproefomvang circa 270 stuks hebben bedragen.

De steekproefomvang van 120 stuks zal menigeen in het gegeven voorbeeld nog hoog voorkomen. De totale variabele controlekosten bedragen echter maar $f 60 / 6^{*} 120=f 1.200,-$.

Veel belangrijker is echter dat de tolerantie te krap bemeten zou kunnen zijn. Dit is een vraagstuk dat naar mijn mening nog niet grondig genoeg is bestudeerd. In een volgend artikel hoop ik dan ook de vraag te behandelen of toedeling van de totale tolerantie in de verantwoording aan controleonderdelen bij statistische steekproeven noodzakelijk is. Als het antwoord ontkennend zou zijn, zouden de getalsverhoudingen drastisch kunnen veranderen, niet alleen in het cijfervoorbeeld, maar ook in de praktijk. 


\section{De plaats van de risico-analyse bij de bepaling van de steelkproefomvang}

In het vorenstaande is geen rekening gehouden met de toepassing van andere controlemiddelen dan de steekproef op de te onderzoeken populaties. De wijze waarop hiermede tegenwoordig wel rekening pleegt te worden gehouden, is door toepassing van risico-analyse. Welke plaats kan deze in de afweging van nut en kosten innemen? Uit deze afweging volgt naar mijn mening welke mate van zekerheid een gebruiker van de accountantsverklaring ten minste kan verlangen. Die mate van zekerheid is belichaamd in de betrouwbaarheid waarmee is vastgesteld dat de tolerantie niet is overschreden. Door middel van risico-analyse zouden de kosten kunnen worden verlaagd en/of de zekerheid kunnen worden verhoogd.

Voorshands zie ik geen objectieve weg waarlangs de verhoging van de mate van zekerheid zou kunnen worden gekwantificeerd. Dit ligt anders voor de kosten. Ik roep nu even het cijfervoorbeeld uit de vorige paragraaf in herinnering. De totale variabele controlekosten bedroegen $f$ 1.200,-; daarboven moeten ook nog vaste kosten, zoals van voorbereiding, planning en van selectie van de te onderzoeken elementen, worden gemaakt. Die moeten niet worden overdreven: de kosten van voorbereiding werpen vaak hun vruchten af voor een reeks van jaren, de planning is een simpele berekening als in de voorgaande paragraaf gegeven, en de selectiekosten zijn bij de huidige stand van de automatisering ook niet hoog.

Als men de verwachting heeft dat de steekproef geheel overbodig gemaakt zou kunnen worden door de uitvoering van een risico-analyse voor het desbetreffende controle-onderdeel plus de uitvoering van een alternatieve controleprocedure, dan kan uitgerekend worden hoeveel geld (= tijd) daarvoor beschikbaar zou zijn. In aansluiting op het cijfervoorbeeld in de voorgaande paragraaf volgt hier een model voor de berekening.
De variabele kosten van de steekproef bedragen: 120 * $f 10,-=$ Stel de vaste kosten van het opzetten van de steekproef op:

7 uur a $f$ 100,- $=\quad f$ 700,waarvan bruikbaar voor 3 jaar:

6 uur à $f 100,-=$
dus elk jaar weerkerende kosten

$$
\begin{array}{r}
f \quad 600,-f \quad 200,- \\
f \quad 100,-\frac{f}{100,-} \\
\hline f 1.500,-
\end{array}
$$

In totaal beschikbaar

voor de risico-analyse plus de alternatieve controleprocedure.

Heeft men de verwachting door de risico-analyse slechts te kunnen besluiten tot een steekproef van geringere omvang, dan kunnen slechts de te besparen variabele steekproefkosten in de vergelijking met de kosten van de risico-analyse worden betrokken. Naar mijn mening moet dan de alternatieve steekproef berekend worden met een risico van niet hoger dan 36,8\%. Dit mogelijk wat vreemd aandoende getal staat voor 1 gedeeld door $e$, het 'natuurlijk getal' ofwel het grondtal van de natuurlijke logaritmen. Gebleken is namelijk dat bij bepaalde thans populaire selectiemethoden, zoals cell sampling en de zeefmethode, steekproeven met een hoger risico dan dit magische getal niet de betrouwbaarheid opleveren die op grond van de veelal gehanteerde tabellen en formules verwacht mag worden (Gill, 1983); bedoelde tabellen en formules zijn namelijk gebaseerd op zuiver lukrake ('random') selectie. Ook betwijfelt menig accountant instinctief het nut van steekproeven met een hoog risico van nietontdekking.

In het cijfervoorbeeld van de voorgaande paragraaf zou een steekproef met een risico van $36,8 \%$ een omvang van 20 moeten hebben. Het voor de risico-analyse beschikbare kostenbedrag zou dus ten hoogste $f 1.200,--20^{*} f 10,-=$ $f 1.000,-$ zijn.

Indien meer expliciet rekening gehouden wordt met de mate van zekerheid die gebruikers van de accountantsverklaring redelijkerwijs mogen verwachten, dan zou de risico-analyse een beschei- 


\section{MAB}

dener plaats krijgen dan in de huidige praktijk. Voorts is het denkbaar dat ook de 'Bayesiaanse' benadering minder belangrijk wordt, omdat daarvoor 'a priori' oordelen van dezelfde aard als bij de risico-analyse vereist zijn.

\section{Omzien in .....}

Het vorenstaande is de vrucht van overwegingen 'achter de schrijftafel'. Hoe zinvol nadenken ook is, het is altijd nuttig daarna nog eens om te zien of daarbij de band met de werkelijkheid niet is losgelaten, om de uitkomsten van de overwegingen te toetsen aan de realiteit in de wereld buiten het studeervertrek. Aan enkele mogelijke punten van kritiek wil ik daarom hierna nog enige aandacht besteden.

Naast fouten in de weergave van feiten kan een verantwoording nog vele andere onvolkomenheden bevatten, zoals in subjectieve schattingen (voorzieningen) en in kwalitatieve mededelingen. Ook daarop dient de accountant zijn aandacht te richten. Dit is echter geen argument om de afweging van kosten en nut bij de controle van de kwantitatieve weergave van feiten achterwege te laten; immers, deze weergave dient ook correct te zijn. Er is geen enkele zekerheid dat onvolkomenheden op andere punten in de verantwoording gecompenseerd worden door onvolkomenheden in de kwantitatieve weergave van feiten.

Voorts kan - opnieuw - de vraag gesteld worden of een afweging van kosten en nut als geschetst maatschappelijk aanvaardbaar is. Bij de in dit artikel geschetste afweging van kosten en nut zijn slechts de eigenaren van de gecontroleerde entiteit in de beschouwing betrokken; de vraag kan rijzen of de vorenstaande algemeen maatschappelijke beschouwing wel recht doet aan andere specifieke belanghebbenden bij de controle van een afzonderlijke verantwoording.

$Z$ Zo voert Baas in een kritiek op de theoretische rechtvaardiging van het steekproefrisico met name kredietverschaffers ten tonele; hij vraagt zich af waarom dezen genoegen zouden moeten nemen met het steekproefrisico, omdat zij immers ook geen aandeel in de kosten dragen (Baas, 1987). Dit argument doet wat merkwaardig aan: als een belanghebbende niet direct of indirect bijdraagt in de kosten, zou hij recht hebben op volledige zekerheid! Voorts hebben kredietverschaffers minder belang bij de door de controle te scheppen zekerheid dan de eigenaren: zij zijn ten aanzien van hun belang, de terugbetaling van het verstrekte krediet en de betaling van de rente, altijd preferent ten opzichte van de eigenaren.

Er zijn echter andere belanghebbenden dan de kredietverschaffers denkbaar, waarvoor het vorenstaande niet of in mindere mate geldt; te denken valt aan werknemers, niet zozeer voor de lonen en de sociale lasten - die immers ook preferent zijn - maar voor hun toekomst, de continuiteit van de gecontroleerde. Te bedenken zij echter, dat de werknemers ook vanuit dit gezichtspunt niet gebaat zijn bij hoge controlekosten: zij tasten de winstcapaciteit aan. Voorts zal een fout die bij het achterwege blijven van ontdekking zou leiden tot verhulling van dreigende discontinuïteit, veel groter zijn dan de tolerantie; de kans op ontdekking is dan veel groter dan uit de eerder beschreven procedure voor de berekening van het aanvaardbare risico volgt.

Hoewel bij zeer specifieke accountantswerkzaamheden uitzonderingen denkbaar zijn, zoals bij fraude-onderzoek, kan in zijn algemeenheid naar mijn mening worden gesteld dat de kosten van integrale accountantscontrole voor het grootste deel uitgaan boven de daarmee geschapen extra zekerheid: volledige controle leidt tot maatschappelijke verspilling. Het komt mij voor dat de maatschappij een dergelijke afweging ook anderszins maakt waar sprake is van controle; te denken valt aan de steekproefsgewijze door de marechaussee en de douane uitgevoerde grenscontroles, waarbij toch grote maatschappelijke belangen in het geding kunnen zijn (drugs).

Een andere, meer technische vraag is de volgende. Omdat tussen de controle-onderdelen de controlekosten per eenheid kunnen variëren en de tolerantiebedragen ten opzichte van de populatietotalen kunnen verschillen, zullen verschillende controle-onderdelen bij de geschetste aanpak 


\section{MAB}

met onderling sterk verschillende steekproefrisico's worden gecontroleerd. De vraag kan rijzen of dit aanvaardbaar is.

Mij dunkt, dat het antwoord bevestigend kan luiden. Het komt mij voor dat dit ook instinctief door een buitenstaander met slechts enige kennis van zaken wordt begrepen. Eenieder die wel eens zijn portemonnaie heeft nageteld en de uitkomst bij de saldi volgens zijn bankafschriften heeft opgeteld, verwacht dat de accountant heeft vastgesteld dat liquide middelen in een jaarrekening tot op de daarin gehanteerde rekeneenheid nauwkeurig worden weergegeven, omdat dit met weinig moeite te constateren valt. Van voorraden beseft een buitenstaander die wel eens een winkelier heeft zien 'balansen', na enig nadenken dat de controle op de exacte weergave aanmerkelijk meer arbeid vergt. Voorshands meen ik dat onderling verschillende risico's geen bezwaar tegen de voorgestelde methode behoeven te zijn.

\section{Slot}

Door de afweging van kosten en nut zou de accountantscontrole wat meer expliciet op het maatschappelijk verkeer georiënteerd zijn. De risico-analyse komt dan in een ander daglicht te staan.

Bij de praktische toepassing is van groot belang de vraag of en hoe toleranties aan de verschillende onderdelen van de te controleren verantwoording moeten worden toegedeeld.

Vorenstaande gedachten moeten uiteraard hun waarde nog bewijzen in het krachtenveld van de wetenschappelijke discussie. Van harte hoop ik dat die zal plaatsvinden.

\section{Literatuur}

Arens, A.A. en Loebbecke, J.K., Auditing, an integrated approach, 4th edition, Prentice Hall, 1988.

Arens, A.A. en Loebbecke, J.K., Auditing, an integrated approach, 5th edition, Prentice Hall, 1991.

AICPA, Statement on Auditing Standards 39, Audit Sampling, juni 1981, opgenomen in Journal of Accountancy, augustus 1981, p. 106

Baas, H., Materiality en Audit Risk, De Accountant, juni 1987 . p. 466.
Blokdijk, J.H., De betekenis van de statistische steekproef voor de leer van de accountantscontrole, MAB, juni 1969, p. 294.

Bromwich. Michael, The Economics of Accounting Standard Setting, Research Studies in Accounting, Prentice-Hall International, 1987

Gill, R.D., The sieve method as an alternative to dollar-unit sampling: the mathematical background, Stichting mathematisch Centrum, Amsterdam, SN 12/83, 1983.

Heerden, A. van, Steekproeven als middel van accountantscontrole, $M A B$, december 1961. p. 453.

Huijgen, C.A. en Plantinga, A., Determinanten van koers/winstverhoudingen, $M A B$, maart 1993, p. 85.

Metzer, R., Kleinere steekproeven door afweging van nut en kosten, De Accountant, januari 1989, p. 237.

NIVRA, Accountantscontrole en steekproef, NIVRA-geschrift 25, Kluwer, 1982.

Riegman, W., Klassieke steekproeven en de produktformule versus Bayesiaanse methoden, De Accountant, november 1991, p. 141.

\section{Appendix}

\section{Inleiding}

Deze Appendix omvat de bewijsvoering voor de bepaling van de steekproef-omvang bij afweging van nut en kosten volgens de in het artikel beschreven inhoud van deze begrippen.

Deze Appendix is niet samengesteld door een vakstatisticus; de gehanteerde wiskunde zal vakstatistici primitief voorkomen. Mogelijk is de wiskunde daardoor voor accountants begrijpelijk. Uitgegaan is van de binomiale verdeling, al wordt in het artikel verwezen naar een tabel van de enkelvoudige Poissonverdeling. Deze laatste is weliswaar een in de accountantspraktijk goed bruikbare benadering van de binomiale verdeling, maar de binomiale verdeling sluit theoretisch beter aan op de in de accountantspraktijk meest voorkomende problematiek. De hiervoor meest volmaakte verdeling, de hypergeometrische, is wegens de moeilijke hanteerbaarheid buiten beschouwing gebleven. 


\section{Legenda}

In het navolgende worden de volgende symbolen gebruikt:

\begin{tabular}{|c|c|}
\hline $\mathrm{T}$ & $\begin{array}{l}\text { Totaalbedrag van de te onderzoeken } \\
\text { populatie }\end{array}$ \\
\hline M & $\begin{array}{l}\text { Tolerantie in de te onderzoeken po- } \\
\text { pulatie }\end{array}$ \\
\hline $\mathrm{K}$ & Koers/winstverhouding \\
\hline B & $\begin{array}{l}\text { Belastingreductiefactor ( } 1 \text { - belasting } \\
\text { perunage) }\end{array}$ \\
\hline C & Controlekosten per eenheid (post) \\
\hline$n$ & Steekproefomvang \\
\hline$p$ & $\begin{array}{l}\text { Toelaatbaar geachte foutenfractie, } \\
\text { dus }=M / T\end{array}$ \\
\hline k & $\begin{array}{l}\text { Aantal in de steekproef aangetroffen } \\
\text { fouten }\end{array}$ \\
\hline$P_{n}(k=k)$ & $\begin{array}{l}\text { De kans op } k \text { fouten in een steek- } \\
\text { proef groot } n\end{array}$ \\
\hline$P_{n}(k \leq k)$ & $\begin{array}{l}\text { De kans op ten hoogste } k \text { fouten in } \\
\text { een steekproef groot } n\end{array}$ \\
\hline & $\begin{array}{l}\text { Het verschil tussen } P_{n}(k=k) \text { en } \\
P_{n+1}(k=k)\end{array}$ \\
\hline$V_{n}(k \leq k)$ & $\begin{array}{l}\text { Het verschil tussen } P_{n}(k \leq k) \text { en } \\
P_{n+1}(k \leq k)\end{array}$ \\
\hline ! & $\begin{array}{l}\text { Faculteit (het gedurig produkt } 1^{*} 2^{*} 3^{\star} \\
\text { enz.) }\end{array}$ \\
\hline
\end{tabular}

3 Afweging van nut en kosten bij een steekproef met goedkeuring uits/uitend bij 0 fouten

De optimaal geachte steekproefomvang wordt bereikt indien de vermindering van de kans op 0 fouten bij de vergroting van de steekproef van $n$ naar $n+1$ stuks, vermenigvuldigd met de tolerantie (M), de koers/winstverhouding (K) en de belastingreductiefactor $(B)$, gelijk is aan de kosten van de controle van één eenheid $(C)$, eveneens vermenigvuldigd met de koers/winstverhouding $(K)$ en de belastingreductiefactor $(B)$.

De vraag is dus: bij welke $n$ geldt

$\left[P_{n}(k=0)-P_{n+1}(k=0)\right] M * K{ }^{*} B=C * K * B ?$

De factoren $K$ en $B$ blijken al dadelijk uit de vergelijking verwijderd te kunnen worden.
Bij toepassing van de binomiale verdeling kan de resterende vergelijking geschreven worden als:

$\left[(1-p)^{n}-(1-p)^{n+1}\right] M=C$

ofwel als:

$[1-(1-p)](1-p)^{n}=C / M$

dus als:

$p(1-p)^{n}=C / M$

of, omdat $p=M / T$, als:

$(1-p)^{n}=\frac{C^{*} T}{M^{2}}$

De waarde voor $(1-p)^{n}$, die berekend kan worden uit $\mathrm{C}$. $\mathrm{T}$ en $\mathrm{M}$, kan worden opgezocht in de kolom $k \leq 0$ in een tabel voor de (enkelvoudige) Poissonverdeling. Uit de voorkolom van deze tabel is de waarde voor het produkt $n$ * $p$ af te lezen; omdat $p=M / T$, die beide bekend zijn, is de verlangde waarde van $n$ hieruit te berekenen.

4 Afweging van nut en kosten bij een steekproef met goedkeuring ook bij één of méér fouten

De vergelijking wordt in dit geval aldus (afgezien van de koers/winst-verhouding en de belastingreductiefactor):

$\left[P_{n}(k \leq k)-P_{n+1}(k \leq k)\right] M=C$

Deze vergelijking leent zich niet voor een gemakkelijke oplossing met behulp van een bestaande tabel. Het linkerdeel van de formule bestaat, naast $M$, uit de som van de verschillen tussen $P_{n}(k=0,1,2$, enz. $)$ en $P_{n+1}(k=0,1,2$, enz. $)$. Om te zien of uit dit geheel een handzame formule is te distilleren, is eerst nagegaan of er een algemene formule te vinden is voor het verschil tussen $P_{n+1}(k=k)$ en $P_{n}(k=k)$. Deze is af te leiden als volgt, uit de algemene formules voor $P(k=k)$ volgens de binomiale verdeling. Deze zijn:

$$
P_{n}(k=k)=\frac{n !}{k !(n-k) !}{ }^{*} p^{k}(1-p)^{n-k}
$$


en dus ook

$$
P_{n+1}(k=k)=\frac{(n+1) !}{k !(n+1+k) !}{ }^{*} p^{k-1}(1-p)^{n-k+1}
$$

Het verschil tussen deze twee grootheden is:

$V_{n}(k=k)=\left[(1-p) \frac{(n+1) !}{k !(n+1-k) !}-\frac{n !}{k !(n-k) !}\right]{ }^{*} p^{k}(1-p)^{n-k}$

Dit kan met enige moeite worden omgewerkt tot:

$V_{n}(k=k)=[\begin{array}{c}\frac{(1-p)(n+1)}{(n+1-k)}-1 \\ k !(n-k) !\end{array} \underbrace{*} p^{k}(1-p)^{n-k}$

Het buiten haakjes geplaatste deel van de formule is nu gelijk aan $P_{n}(k=k)$; de formule kan nu verder vereenvoudigd worden tot:

$V_{n}(k=k)=\frac{p(n+1)-k}{n+1-k} P_{n}(k=k)$

$\mathrm{Nu}$ rest nog de bepaling van de formule voor $V_{n}(k \leq k)$, de som van de verschillen $V_{n}(k=k)$. Nu is uit de in paragraaf 3 hiervóór gegeven bewijsvoering af te leiden dat $V_{n}(\underline{k}=0)$ gelijk is aan $p$ * $P_{n}(k=0)$. Bij afzonderlijke afleiding van de formules voor $V_{n}(k \leq 1)$ en $V_{n}(k \leq 2)$ zijn deze gebleken gelijk te zijn aan $p^{*} P_{n}(k=1)$ respectievelijk $P_{n}(k=2)$. Daaruit is het vermoeden gerezen dat:

$V_{n}(k \leq k)=p{ }^{*} P_{n}(k=k)$

Het loont dus de moeite na te gaan of dit in het algemeen waar is, met andere woorden: of $V_{n}(k \leq k)$ altijd gelijk is aan $p^{*} P_{n}(k=k)$. Dit zou bewezen zijn als:

$V_{n}(\underline{k}=k)+p{ }^{*} P_{n}(k=k-1)=p * P_{n}(k=k)$

Daarvoor is het weer zinvol na te gaan hoe in het algemeen $P_{n}(k=k)$ af te leiden valt uit $P_{n}(k=k-1)$. Daartoe dient
$P_{n}(k=k) \quad=\frac{n !}{k !(n-k) !} \quad * p^{k} \quad(1-p)^{n-k}$

gedeeld te worden door

$P_{n}(k=k-1)=\frac{n !}{(k-1) !(n-k+1) !}{ }^{*} p^{k-1 *}(1-p)^{n-k-1}$

hetgeen oplevert:

$P_{n}(k=k)=\underline{n-k+1} * \underline{p}$

$P_{n}(\underline{k}=k-1) \quad k \quad 1-p$

ofwel:

$P_{n}(k=k-1)=\frac{k(1-p)}{p(n-k+1)} * P_{n}(k=k)$

De te bewijzen gelijkheid:

$V_{n}(k=k)+p{ }^{*} P_{n}(k=k-1)=p{ }^{*} P_{n}(k=k)$,

kan nu met gebruikmaking van de eerder ontwikkelde formules, ook geschreven worden als volgt:

$$
\frac{p(n+1)-k^{*}}{n+1-k} P_{n}(k=k)+p * \underline{k(1-p)}{ }^{*} P_{n}(k=k)=p^{*} P_{n}(k=k)
$$

waaruit snel te zien valt dat de te bewijzen gelijkheid inderdaad bestaat.

Dus geldt:

$V_{n}(k<k)=p^{*} P_{n}(k=k)$

waarmee de in het artikel beschreven procedure is gerechtvaardigd.

\section{Slot}

De gevonden formule heeft een elegante eenvoud, die doet vermoeden dat er een eenvoudiger redenering te ontwerpen is die tot dezelfde uitkomst leidt. Ook het feit dat een cumulatief verschil tussen kansen (namelijk bij $n$ en $n+1$ ) een eenvoudige functie is van een enkelvoudige kans, intrigeert. De verklaring hiervoor kan mogelijk tot een dieper inzicht leiden, waardoor andere bij de accountantscontrole zinvolle mogelijkheden kunnen blijken. 